Original Research Article

\title{
Cross sectional study to assess the awareness of pharmacovigilance among post graduate residents of tertiary care medical college hospital of central India
}

\author{
Pooja Solanki Mishra1 ${ }^{1}$ Gopal Gudsurkar ${ }^{2 *}$
}

\begin{abstract}
${ }^{1}$ Department of Pharmacology, MGM Medical College, Indore, Madhya Pradesh, Maharashtra, India

${ }^{2}$ Department of Pharmacology, Dr. Ulhas Patil Medical College and Hospital Jalgaon,

Maharashtra, India
\end{abstract}

Received: 29 January 2018 Accepted: 03 February 2018

\section{*Correspondence to: Dr. Gopal Gudsurkar, Email: drgopalofficial@ gmail.com}

Copyright: () the author(s), publisher and licensee Medip Academy. This is an openaccess article distributed under the terms of the Creative Commons Attribution NonCommercial License, which permits unrestricted noncommercial use, distribution, and reproduction in any medium, provided the original work is properly cited.

\begin{abstract}
Background: Pharmacovigilance knowledge and awareness in post graduate student doctors is key factor for proper implementation of PvPI. This study was planned to evaluate the knowledge \&awareness of pharmacovigilance in post graduate students in tertiary care centre in Indore.

Methods: It was a single point cross sectional questionnaire-based study conducted in a tertiary care Institute MGM Medical College \& M.Y. Hospital in the state of Madhya Pradesh at Indore. It was conducted among post graduate student doctors from various clinical departments. Total of 150 questionnaires were distributed, 115 of them were returned back and were analysed.

Results: Overall knowledge level was satisfactory. 91.30\% knew about ADR while $95 \%$ were aware about PVPI. $13 \%$ knew about local AMC at Indore while only $4.34 \%$ knew global centre for Pharmacovigilance is at Sweden Uppsala. 86.95\% thought Med watch as global database for ADR against only $13 \%$ knew its Vigibase. 96.50\% thought ADR reporting is necessary. 97.40\% thought it should be included in UG curriculum. 95.65\% had not reported any ADR till date while $86.95 \%$ had not seen an ADR form.

Conclusions: Post graduate doctors are the prime candidates to impart the importance of pharmacovigilance. The study strongly suggested that there was a great need to create awareness among the post graduate doctors to improve the reporting of ADRs.
\end{abstract}

Keywords: ADR, Pharmacovigilance, PvPI

\section{INTRODUCTION}

Drugs used for therapeutic purpose are liable to produce adverse drug reaction even when used in therapeutic doses. Adverse drug reactions can be defined as an appreciably harmful or unpleasant reaction, resulting from an intervention related to the use of a medicinal product, which predicts hazard from future administration and warrants prevention or specific treatment, or alteration of the dosage regimen, or withdrawal of the product. ${ }^{1}$
According to World Health Organization (WHO) definition, an ADR is any noxious, unintended, and undesired effect of a drug, which occurs at the doses which are used in humans for prophylaxis, diagnosis, or therapy. ${ }^{2}$

So, to monitor ADR in proper systematic way pharmacovigilance was started as a global need to control ADR and problems related to it. Pharmacovigilance is, "The science and the activities which relate to the detection, assessment, understanding and the prevention of adverse effects or any other drug-related problems. ${ }^{3}$ 
Doctors, nurses, pharmacists are the key stakeholders of active reporting of $\mathrm{ADR}$ for any pharmacovigilance programme. Spontaneous reporting by various stakeholders is most important for monitoring known and unknown ADRs of medicines. ${ }^{4,5}$

The Uppsala Monitoring Centre (UMC, WHO) at Sweden is the apex body to maintain the international database of the adverse drug reaction reports. It has been estimated that only $6-10 \%$ of all the ADRs are reported worldwide which is very less. ${ }^{6}$

India is a participant of global pharmacovigilance programme but still due to lack of robust reporting structure and lack of awareness in doctors and other healthcare professionals; we still are miles behind in reporting ADRs.

For implement Pharmacovigilance programme in India efficiently and improve data collection The Pharmacovigilance Programme of India (PvPI) was initiated by the Government of India in July 2010 with AIIMS (All India Institute of Medical Sciences), New Delhi as NCC (National coordinating centre). The NCC was shifted from AIIMS, New Delhi to IPC (Indian Pharmacopeia Commission), Ghaziabad on 15th April $2011 .^{7}$

AMCs (adverse drug reaction monitoring centres) are the principal data collecting centre in this programme. These are situated in various medical colleges and hospitals across the country. These centres collect individual case safety reports (ICSRs) and follow up the cases to gather necessary supplementary Information and perform scientific evaluation. ${ }^{8}$

Mahatma Gandhi Memorial medical college Indore is a tertiary care centre in Madhya Pradesh and every year around 200 post graduates across different specialities are enrolled who actively manage OPDs, ICU and other health care services. Till date no KAP study was done regarding pharmacovigilance awareness among post graduate students in the tertiary care institute. So, this study was aimed to evaluate their knowledge and attitude towards Pharmacovigilance and PvPI.

\section{METHODS}

This was a cross sectional, questionnaire-based survey which was conducted in a tertiary care Institute MGM Medical College and M.Y. Hospital in the state of Madhya Pradesh at Indore. It was conducted among post graduate student doctors from various clinical departments. The study instrument was a pre-designed 20 questionnaires which were structured to obtain information on the knowledge of the ADRs reporting and the attitudes towards the reporting.

There were 13 questions designed to test knowledge, 4 for attitude and 3 for practice.
The doctors were requested to complete the questionnaire and to return it within 1 day to their respective departmental offices.

\section{Statistical analysis}

The questionnaire was analysed and question-wise percentage values were calculated with the help of Microsoft excel spread sheet in MS Office 2010.

\section{RESULTS}

Total of 150 questionnaires were distributed, 115 of them were returned back and were analysed.

Percentage of responders: $(115 / 150)$ X $100=76.66 \%$

The percentage based calculation of all the responses were made by taking 150 (the total no. of responders) as the denominator.

Table 1 shows, $91.30 \%$ knew about ADR while $95 \%$ were aware about PVPI. $60.86 \%$ thought that important purpose of Pharmacovigilance is to calculate incidence of ADR.

$82.60 \%$ knew about regulatory body of ADR monitoring is CDSCO.

$69.50 \%$ knew apex body in India for Pharmacovigilance is IPC Ghaziabad.

Only $13 \%$ knew about local AMC is at SAIMS medical college Indore while only $4.34 \%$ knew global centre for Pharmacovigilance is at Sweden Uppsala.

$52 \%$ thought it as duty of doctor only to report ADR and $47.82 \%$ knew all healthcare professionals can report ADR. $86.95 \%$ thought Med watch as global database for ADR against only $13 \%$ knew its Vigibase.

Table 2 shows, $96.50 \%$ thought ADR reporting is necessary. $86.9 \%$ thought it should be made mandatory for all health care professionals.

$97.40 \%$ thought it should be included in UG curriculum and also the hospital should be made AMC.

Table 3 shows, 95.65\% have not reported any ADR till date. $86.95 \%$ have not seen an ADR form. $60 \%$ did not know how to report while $20 \%$ had fear of legal consequences after reporting.

\section{DISCUSSION}

WHO has defined Pharmacovigilance as the science and activities relating to the detection, assessment, understanding and prevention of the adverse effects (AE), particularly long and short term side effects of medicines or any other drug related problems..$^{9,10}$ 
Table 1: Responses to knowledge based questions.

\begin{tabular}{|c|c|c|c|}
\hline Sr No. & $\begin{array}{l}\text { Most frequently } \\
\text { answered \% }\end{array}$ & $\begin{array}{l}\text { Correct answer } \\
\%\end{array}$ & $\begin{array}{l}\text { Most commonly wrong } \\
\text { answered } \%\end{array}$ \\
\hline 1. Do you know what an ADR is? & $\begin{array}{l}\text { Adverse Drug Reaction } \\
: 105 / 115 \\
91.30 \%\end{array}$ & $\begin{array}{l}\text { Adverse Drug Reaction: } \\
105 / 115 \\
91.30 \%\end{array}$ & $\begin{array}{l}\text { Acute Drug Reaction } \\
10 / 115 \\
8.69 \%\end{array}$ \\
\hline 2. Define Pharmacovigilance? & $\begin{array}{l}\text { The science of monitoring } \\
\text { ADR's happening in a } \\
\text { Hospital :25/115 } \\
21.73 \%\end{array}$ & $\begin{array}{l}\text { The detection, assessment, } \\
\text { understanding and } \\
\text { prevention of adverse } \\
\text { effects: } 90 / 11578.26 \%\end{array}$ & $\begin{array}{l}\text { The science of monitoring } \\
\text { ADR's happening in a } \\
\text { Hospital: } 25 / 115 \\
21.73 \%\end{array}$ \\
\hline $\begin{array}{l}\text { 3. Are you aware of } \\
\text { Pharmacovigilance Programme of } \\
\text { India? }\end{array}$ & $\begin{array}{l}\text { Yes: } 110 / 115 \\
95.65 \%\end{array}$ & $\begin{array}{l}\text { Yes: } 110 / 115 \\
95.65 \%\end{array}$ & $\begin{array}{l}\text { No: } 5 / 115 \\
4.5 \%\end{array}$ \\
\hline $\begin{array}{l}\text { 4. The important purpose of } \\
\text { Pharmacovigilance is }\end{array}$ & $\begin{array}{l}\text { To calculate incidence of } \\
\text { ADR's } \\
70 / 115 \\
60.86 \%\end{array}$ & $\begin{array}{l}\text { To identify unrecognized } \\
\text { ADR's } \\
45 / 115 \\
39.13 \%\end{array}$ & $\begin{array}{l}\text { To calculate incidence of } \\
\text { ADR's } \\
70 / 115 \\
60.86 \%\end{array}$ \\
\hline $\begin{array}{l}\text { 5. Which of the following methods } \\
\text { is commonly employed by the } \\
\text { pharmaceutical companies to } \\
\text { monitor adverse drug reactions of } \\
\text { new drugs once they are launched } \\
\text { in the market? }\end{array}$ & $\begin{array}{l}\text { Meta-analysis } \\
40 / 115 \\
34.78 \%\end{array}$ & $\begin{array}{l}\text { Post Marketing } \\
\text { Surveillance (PMS) } \\
\text { studies. } \\
75 / 115 \\
65.21 \%\end{array}$ & $\begin{array}{l}\text { Meta-analysis } \\
40 / 115 \\
34.78 \%\end{array}$ \\
\hline $\begin{array}{l}\text { 6. In India which Regulatory body } \\
\text { is responsible for monitoring of } \\
\text { ADR's? }\end{array}$ & $\begin{array}{l}\text { Central Drugs Standard } \\
\text { Control Organization } \\
95 / 115 \\
82.60 \%\end{array}$ & $\begin{array}{l}\text { Central Drugs Standard } \\
\text { Control Organization } \\
95 / 115 \\
82.60 \%\end{array}$ & $\begin{array}{l}\text { Central Drug Research } \\
\text { Institute } \\
20 / 115 \\
17.39 \% \\
\end{array}$ \\
\hline $\begin{array}{l}\text { 7. The national centre for } \\
\text { monitoring ADRs in India is } \\
\text { located at: }\end{array}$ & $\begin{array}{l}\text { Indian Pharmacopeia } \\
\text { Commission, Ghaziabad } \\
80 / 115 \\
69.56 \%\end{array}$ & $\begin{array}{l}\text { Indian Pharmacopeia } \\
\text { Commission, Ghaziabad } \\
80 / 115 \\
69.56 \%\end{array}$ & $\begin{array}{l}\text { AIIMS, New Delhi } \\
35 / 115 \\
30.43 \%\end{array}$ \\
\hline $\begin{array}{l}\text { 8. Which of the following is the } \\
\text { AMC of the region? }\end{array}$ & $\begin{array}{l}\text { GMC Bhopal } \\
100 / 115 \\
86.95 \%\end{array}$ & $\begin{array}{l}\text { SAIMS Indore } \\
15 / 115 \\
13.04 \%\end{array}$ & $\begin{array}{l}\text { GMC Bhopal } \\
100 / 115 \\
86.95 \%\end{array}$ \\
\hline $\begin{array}{l}\text { 9. Rare ADRs can be identified in } \\
\text { the following phase of a clinical } \\
\text { trial }\end{array}$ & $\begin{array}{l}\text { During phase- } 4 \text { clinical } \\
\text { trials } \\
105 / 115 \\
91.30 \%\end{array}$ & $\begin{array}{l}\text { During phase- } 4 \text { clinical } \\
\text { trials } \\
105 / 115 \\
91.30 \%\end{array}$ & $\begin{array}{l}\text { During phase- } 3 \text { clinical } \\
\text { trials } \\
10 / 115 \\
8.69 \%\end{array}$ \\
\hline $\begin{array}{l}\text { 10. The international centre for } \\
\text { adverse drug reaction monitoring is } \\
\text { located in }\end{array}$ & $\begin{array}{l}\text { Unites States of America } \\
110 / 115 \\
95.65 \%\end{array}$ & $\begin{array}{l}\text { Sweden } \\
05 / 115 \\
4.34 \%\end{array}$ & $\begin{array}{l}\text { Unites States of America } \\
110 / 115 \\
95.65 \%\end{array}$ \\
\hline $\begin{array}{l}\text { 11. The healthcare professionals } \\
\text { responsible for reporting ADR in a } \\
\text { hospital is/are }\end{array}$ & $\begin{array}{l}\text { Doctor } \\
60 / 115 \\
52.17 \%\end{array}$ & $\begin{array}{l}\text { Doctor, nurses and } \\
\text { pharmacists } \\
55 / 115 \\
47.82 \%\end{array}$ & $\begin{array}{l}\text { Doctor } \\
60 / 115 \\
52.17 \%\end{array}$ \\
\hline $\begin{array}{l}\text { 12. Which one of the following is } \\
\text { the 'WHO online database' for } \\
\text { reporting ADRs? }\end{array}$ & $\begin{array}{l}\text { Med watch } \\
100 / 115 \\
86.95 \%\end{array}$ & $\begin{array}{l}\text { Vigibase } \\
15 / 115 \\
13.04 \%\end{array}$ & $\begin{array}{l}\text { Med watch } \\
100 / 115 \\
86.95 \%\end{array}$ \\
\hline $\begin{array}{l}\text { 13. Which of the following scales } \\
\text { is most commonly used to establish } \\
\text { the causality of an ADR? }\end{array}$ & $\begin{array}{l}\text { Schumock and Thornton } \\
\text { scale } \\
95 / 115 \\
82.60 \%\end{array}$ & $\begin{array}{l}\text { Naranjo algorithm } \\
20 / 115 \\
17.40 \%\end{array}$ & $\begin{array}{l}\text { Schumock and Thornton } \\
\text { scale } \\
95 / 115 \\
82.60 \%\end{array}$ \\
\hline
\end{tabular}

Previous reported studies have found that underreporting of ADR is related with shortcomings in the knowledge and attitude of health care professionals. ${ }^{11-13}$
Hence, Authors planned this study to increase the awareness and practice among Post graduate students at the centre. 
Table 2: Responses to attitude based questions.

\begin{tabular}{|c|c|c|c|}
\hline $\begin{array}{l}\text { Do you think } \\
\text { Pharmacovigilance } \\
\text { should be taught in } \\
\text { detail during } \\
\text { undergraduate } \\
\text { curriculum? }\end{array}$ & $\begin{array}{l}\text { Yes } \\
112 / 115 \\
97.40 \%\end{array}$ & $\begin{array}{l}\text { Yes } \\
112 / 115 \\
97.40 \%\end{array}$ & $\begin{array}{l}\text { No } \\
3 / 115 \\
2.60 \%\end{array}$ \\
\hline $\begin{array}{l}\text { Do you think } \\
\text { reporting of adverse } \\
\text { drug reaction is } \\
\text { necessary? }\end{array}$ & $\begin{array}{l}\text { Yes } \\
111 / 115 \\
96.52 \%\end{array}$ & $\begin{array}{l}\text { Yes } \\
111 / 115 \\
96.52 \%\end{array}$ & $\begin{array}{l}\text { No } \\
04 / 115 \\
3.50 \%\end{array}$ \\
\hline $\begin{array}{l}\text { Do you think } \\
\text { reporting of ADR } \\
\text { should be made } \\
\text { mandatory for } \\
\text { health care } \\
\text { professionals? }\end{array}$ & $\begin{array}{l}\text { Yes } \\
100 / 115 \\
86.95 \%\end{array}$ & $\begin{array}{l}\text { Yes } \\
100 / 115 \\
86.95 \%\end{array}$ & $\begin{array}{l}\text { No } \\
15 / 115 \\
13.40 \%\end{array}$ \\
\hline $\begin{array}{l}\text { Do you think the } \\
\text { hospital should be } \\
\text { AMC? }\end{array}$ & $\begin{array}{l}\text { Yes } \\
112 / 115 \\
97.40 \%\end{array}$ & $\begin{array}{l}\text { Yes } \\
112 / 115 \\
97.40 \%\end{array}$ & $\begin{array}{l}\text { No } \\
3 / 115 \\
2.60 \%\end{array}$ \\
\hline
\end{tabular}

Table 3: Responses to practice based questions.

\begin{tabular}{|c|c|c|}
\hline $\begin{array}{l}\text { Have you ever } \\
\text { seen the ADR } \\
\text { reporting } \\
\text { form? }\end{array}$ & $\begin{array}{l}\text { No } \\
100 / 115 \\
86.95 \%\end{array}$ & $\begin{array}{l}\text { Yes } \\
15 / 115 \\
13.40 \%\end{array}$ \\
\hline $\begin{array}{l}\text { Have you ever } \\
\text { reported an } \\
\text { ADR? }\end{array}$ & $\begin{array}{l}\text { No } \\
110 / 115 \\
95.65 \%\end{array}$ & $\begin{array}{l}\text { Yes } \\
05 / 115 \\
4.34 \%\end{array}$ \\
\hline $\begin{array}{l}\text { What practical } \\
\text { difficulties you } \\
\text { have in } \\
\text { reporting ADR } \\
\text { at the center? }\end{array}$ & \multicolumn{2}{|c|}{$\begin{array}{l}\text { Don't know how to report ADR } \\
69 / 11560 \% \\
\text { ADRs are already documented in } \\
\text { literature } 12 / 11510 \% \\
\text { Don't know how to fill up ADR } \\
\text { form } 12 / 11510 \% \\
\text { Fear of legal issues due to reporting } \\
\text { ADR } 22 / 11520 \%\end{array}$} \\
\hline
\end{tabular}

Most important thing about KAP studies like these is response of participating candidates. This study had a very good response rate, $76.66 \%$.

It shows most of the candidates were keen towards the subject of pharmacovigilance.

As far as knowledge is concerned, 93.30\% knew ADR while $95.65 \%$ were aware about PvPI.

But only $39.13 \%$ knew its actual purpose to identify unrecognised ADR's. This shows PG students have good approach towards this programme but they lack the training about it.

$82.60 \%$ knew the apex body to monitor ADR is CDSCO and $69.56 \%$ knew the apex body of PVPI is IPC Ghaziabad. $91.30 \%$ knew about phase 4 trials in which rare ADR's are identified. Above three values indicate that basic theoretical knowledge about ADR and PvPI is very good among the participating post graduates.

Advanced knowledge like local AMC was known to only $13.04 \%$ while global centre at Sweden Uppsala was known to only $4.34 \%$. it shows lack of training in PVPI.

$52.17 \%$ thought its only duty of doctors while $47.82 \%$ actually knew that any healthcare professional can report an ADR which further highlights importance of training in PVPI among budding health care professionals.

Attitude of the participating doctors was very much positive. $86 \%$ said that ADR reporting should be made mandatory to all health care professionals. $97.40 \%$ were of opinion to include pharmacovigilance from undergraduate syllabus itself and also the tertiary care centre should be made a recognised AMC to report ADR.

Practice part was found to be very much poor. $86.95 \%$ had never seen an ADR form ever while $95.65 \%$ never reported any ADR till date. This is a significant observation in this study because this clearly shows total lack of practice and training in PVPI.

This observation was further confirmed by asking the difficulties in reporting an ADR.

$60 \%$ did not know how to report an ADR while $20 \%$ was afraid of legal consequences. $10 \%$ had seen but did not know how to fill up ADR form. Another $10 \%$ were reluctant to report an ADR because it was already documented in literature.

For improve the spontaneity in the reporting rates, the doctors suggested regular organization of training programmes and an uncomplicated reporting system with a quick feedback regarding their specific reports.

A similar study which was demonstrated that an educational intervention could increase the physicians' awareness on ADRs and that the physicians would be able to incorporate the knowledge that they gained from their training into their everyday clinical practice. ${ }^{14}$

In some studies, the health care professionals were found to be highly aware of ADR reporting and were reporting ADRs. Authors found that majority of the health care professionals had good knowledge about pharmacovigilance and considered it essential. ${ }^{15}$

\section{CONCLUSION}

In conclusion, this study strongly suggested that there was a great need to create awareness among the post graduate doctors to improve the reporting of ADRs. Post graduate doctors are the prime candidates to impart the importance of pharmacovigilance because they are the ones who actively are in touch with patients regularly and also, they are future specialists. 
If they get habit to report the ADR's it will greatly improve the quality of data collection and also boost goals of PVPI.

The training sessions must clarify the roles of the various healthcare professionals in pharmacovigilance. There should be closer relationship between the doctors and the pharmacovigilance centres.

\section{ACKNOWLEDGEMENTS}

Authors would like to thank all the reporters for reporting and the Pharmacovigilance Program of India for providing the platform to contribute reports to the database.

\section{Funding: No funding sources}

Conflict of interest: None declared

Ethical approval: The study was approved by the Institutional Ethics Committee

\section{REFERENCES}

1. Edwards IR, Aronson JK. Adverse drug reactions: definitions, diagnosis and management. Lancet. 2000;7(356):1255-9.

2. Classen DC, Pestotnik SL, Evans RS. The adverse drug events in hospitalized patients. JAMA. 1997;277(4):301-6. PMID: 9002492. Available at: http://www.ncbi.nlm.nih.gov/pubmed/9002492.

3. The World Health Organization. Safety of medicines: A guide to detecting and reporting adverse drug reactions. Geneva. 2002. WHO/ EDM/QSM/2002 2.

4. The learning centre continuing pharmacy education; fall. Canada: University of British Columbia. Pharmacists are number one. 1999.

5. Backstrom M, Mjorndal T, Dahlqvist R, NordkvistOlsson T. Attitudes of reporting adverse drug reactions in northern Sweeden. Eur J Clinpharmacol. 2000;56:729-32.

6. Feely J, Moriarty S, O'Connor P. Stimulating the reporting of an ad verse drug reaction by using a fee. $\mathrm{Br}$ Med J. 1990;300:22-3. Available at: http://www.ncbi.nlm.nih.gov/pmc/articles/PMC1661 889/ pdf/bmj00160-0028.pdf.

7. Pharmacovigilance Programme of India. Guidance Document for Spontaneous Adverse Drug Reaction Reporting. 2013;1:1-69.
8. Abubakar AR, Simbak NB, Haque M. ASystematic Review of Knowledge, Attitude and Practice on Adverse Drug Reactions and Pharmacovigilance among Doctors. J App Pharm Sci. 2014;4(11):117-27.

9. Madhan R, Parthsarathi G. Attitudes and perceptions of medical practitioners-Adverse drug reactions reporting. Asian journal of pharmaceutical and clinical research. 2009;2:184-9.

10. Sweis D, Wong IC. A survey on factors that could affect adverse drug reaction reporting according to hospital pharmacists in Great Britain. Drug Saf. 2000;23:165-72.

11. Gupta P, Udupa A. Adverse drug reaction reporting and Pharmacovigilance: knowledge, attitude and perception among resident doctors. J Pharm Sci Res. 2011;3:1064-9.

12. Eland IA, Belton KJ, Van Grootheest AC, Meiners AP, Strickers BH. Attitudinal survey of voluntary reporting of adverse drug reactions. $\mathrm{Br} \mathrm{J}$ clin Pharmacol. 1999;48:623-27.

13. Green CF, Mottrom DR, Brown AM, Rowe PH. Attitudes of hospital pharmacists to adverse drug reactions and yellow card scheme: A qualitative study. Int J Pharm Pract. 1999;7:247-55.

14. Tabali M, Jeschke E, Bockelbrink A, Witt CM, Willich SN, Ostermann T, et al. An educational intervention to improve the physician reporting of the adverse drug reactions (ADRs) in a primary care setᄀiting in the complementary and alternative medicine programs. BMC Public Health. 2009;9:274. Available at: http://www.biomedcentral.com/14712458/9/274.

15. Muraraiah S, Rajarathna K, Sreedhar D, Basavalingu D, Jayanthi CR. A questionnaire study to assess the knowledge, attitude and practice of Pharmacovigilance in a paediatric tertiary care centre. J Chem Pharm Res. 2011;3:416-22.

Cite this article as: Mishra PS, Gudsurkar G. Cross sectional study to assess the awareness of pharmacovigilance among post graduate residents of tertiary care medical college hospital of central India. Int J Basic Clin Pharmacol 2018;7:386-90. 